\title{
SIMON FRASER UNIVERSITY RADIOCARBON DATES II
}

\author{
$\mathrm{K}$ A HOBSON and D E NELSON
}

Archaeology Department, Simon Fraser University

Burnaby, British Columbia, Canada V5A 1S6

This list reports measurements made on archaeologic samples by our laboratory from September 1980 to May 1982. Results of measurements made during that period which lack review by submitters will be reported in a subsequent date list. Dates were obtained by liquid scintillation counting of benzene using the laboratory procedure outlined previously ( $\mathrm{R}, 1982$, v 24, p 344-351). All dates are expressed in ${ }^{14} \mathrm{C}$ years relative to AD 1950 based on the Libby half-life for ${ }^{14} \mathrm{C}$ of $5568 \mathrm{yr}$. The laboratory standard continues to be ANU sucrose. Data analysis is now performed with the aid of an RT-11 microcomputer interfaced with our Packard model 3255 LS counter. Dates have been corrected for isotopic fractionation only when the $\delta^{13} \mathrm{C}$ value is given. No corrections have been made for natural ${ }^{14} \mathrm{C}$ variations. The following descriptions of samples are based on information provided by the submitters.

\section{ACKNOWLEDGMENTS}

We would like to thank the Imperial Oil Corporation (Canada) Ltd for funding assistance from 1977 to 1982.

\section{British Columbia}

\section{A. Canada}

\section{Shuswap house-pit series}

Charcoal and bone from EdQs 14 site $\left(50^{\circ} 30^{\prime} 09^{\prime \prime} \mathrm{N}, 119^{\circ} 04^{\prime} 06^{\prime \prime} \mathrm{W}\right)$ $\mathrm{N}$ side of Shuswap R, $6.43 \mathrm{~km}$ E of township of Enderby. This site consists of 3 small ( $5 \mathrm{~m}$ diam) house-pit depressions and 86 small ( 1 to $2 \mathrm{~m}$ ) circular, cellar cache-pit depressions. Previous archaeol research in region suggested that rectilinear house-pits were local architectural specialization and were in use for over $1000 \mathrm{yr}$, ca $\mathrm{AD} 650$ to 1750 . The following ${ }^{14} \mathrm{C}$ dates appear to confirm this hypothesis. Samples coll and subm by Gordon Mohs, Dept Archaeol, Simon Fraser Univ.

SFU-50.

$490 \pm 130$

Charcoal from $\mathrm{S}$ wall of House-pit I, $20 \mathrm{~cm}$ below surface. Sample dates main occupational horizon within house pit.

SFU-51.

$870 \pm 180$

Charcoal from pocket of fire-cracked rock at base of main component of House-pit II, 20 to $30 \mathrm{~cm}$ below surface. Sample dates upper occupational horizon within house pit.

SFU-56.

$430 \pm 100$

Charcoal from cultural deposits on floor of House-pit I, 60 to $70 \mathrm{~cm}$ below surface. Sample dates main occupational horizon within Housepit I. 
SFU-57.

Collagen extracted from deer antler from rimfall deposits on $S$ side of House-pit I, 20 to $30 \mathrm{~cm}$ below surface. This is only date of earlier component of site.

\section{Kain Meat Cache site}

SFU-73.

$480 \pm 100$

$\delta^{1 s} \mathrm{C}=-17.9 \%$

Collagen from unid. mammal bone in soil matrix 0 to $10 \mathrm{~cm}$ beneath rock cairn at DiLw-12 site $\left(49^{\circ} 51^{\prime} 35^{\prime \prime} \mathrm{N}, 99^{\circ} 49^{\prime} 45^{\prime \prime} \mathrm{W}\right)$. Sample dates this type of feature to Late Prehistoric period. Sample coll and subm by B A Nicholson, Dept Archaeol, Simon Fraser Univ.

\section{Kain Butchering site}

Collagen from unid. mammal bones excavated at DiLw-11 site $\left(49^{\circ}\right.$ $\left.51^{\prime} 30^{\prime \prime} \mathrm{N}, 99^{\circ} 50^{\prime} 00^{\prime \prime} \mathrm{W}\right)$. Site contains at least two superimposed occupations. Samples coll and subm by B A Nicholson.

SFU-72.

$1700 \pm 100$

Collagen from mammal bone 50 to $70 \mathrm{~cm}$ below surface.

SFU-75.

$\delta^{19} \mathrm{C}=-18.8 \%$ o

Collagen from mammal bone 10 to $25 \mathrm{~cm}$ below surface.

\section{Unnamed Site I}

\section{SFU-74.}

Collagen from unid. mammal bone from lower terrace at DiLx-3 site $\left(49^{\circ} 52^{\prime} 00^{\prime \prime} \mathrm{N}, 99^{\circ} 55^{\prime} 10^{\prime \prime} \mathrm{W}\right)$. Sample coll and subm by B A Nicholson.

\section{Canal Flats series}

Charcoal and peat from $\mathrm{EbPw}-1$ site $\left(50^{\circ} 11^{\prime} 00^{\prime \prime} \mathrm{N}, 115^{\circ} 49^{\prime} 10^{\prime \prime} \mathrm{W}\right)$, $\mathrm{E}$ side of Columbia Lake, $3.2 \mathrm{~km} \mathrm{~N}$ of Canal Flats. Site covers area 11 ha and is characterized by 2 surface depressions and 2 pictograph panels. Samples coll and subm by Gordon Mohs.

\section{SFU.77.}

$$
110 \pm 80
$$

Charcoal from base of rock-lined pit depression 40 to $50 \mathrm{~cm}$ below surface. Sample dates roasting pit. Comment: green residue present in combustion bomb after combustion indicates possible grease residue in sample.

SFU-78.

$$
3160 \pm 100
$$

Charcoal from charcoal lens adjacent to pictograph panel. As much ocher was recovered above and below this lens; sample subm to date panel. 
SFU-79.

$800 \pm 80$

Charcoal from layer of hearth rock from floor of house pit 20 to $30 \mathrm{~cm}$ below surface. Sample represents only known date for house pit occupation with Rocky Mt trench.

SFU-80.

$480 \pm 80$

Charcoal from post cavity on rim of roasting pit depression 30 to $40 \mathrm{~cm}$ below surface.

SFU-89.

$330 \pm 80$

Charcoal from layer of hearth rock of roasting pit 20 to $30 \mathrm{~cm}$ below surface. Comment: sample consistent with SFU-80 from same feature.

SFU-99.

$100 \pm 80$

Charcoal from layer of hearth rock near center of roasting pit 20 to $30 \mathrm{~cm}$ below surface.

SFU-108.

$140 \pm 80$

Peat-like organic matter from rock-lined pit depression at base of roasting pit. Comment: date is consistent with SFU-77 and -99 from same feature

\section{Kitselas Canyon Series I}

Charcoal excavated from Paul Mason site, GdTc-16 (54 $36^{\prime} 28^{\prime \prime} \mathrm{N}$, $128^{\circ} 25^{\prime} 04^{\prime \prime}$ W), E side of Skeena R, Kitselas Canyon, $16 \mathrm{~km}$ NE of Terrace. This is village site at $+138 \mathrm{~m}$. Samples subm to date beginning and length of occupation; coll and subm by G F MacDonald for Parks Canada, P O Box 2989, Calgary, Alberta.

SFU-132.

$3130 \pm 100$

Charcoal.

SFU-133.

$3780 \pm 120$

Charcoal.

SFU-134.

$3230 \pm 160$

Charcoal.

SFU-135.

$890 \pm 160$

Charcoal.

\section{Edziza series}

Charcoal, wood, and peat from archaeol survey of Mt Edziza region $\left(57^{\circ} 20^{\prime}\right.$ to $35^{\prime} \mathrm{N}, 130^{\circ} 30^{\prime}$ to $\left.45^{\prime} \mathrm{W}\right)$. Samples coll and subm by Knut Fladmark, Dept Archaeol, Simon Fraser Univ.

SFU-129.

$4870 \pm 120$

$\delta^{18} \mathrm{C}=-25 \%$

Charcoal from 35 to $40 \mathrm{~cm}$ below surface, overlying gray ash layer and underlying compact organic clays. Sample subm to date assoc flake arti- 
facts from HiTp63. Comment: sample too small for base rinse. Comment (KRF): sample dates microblade component at Ohio level.

SFU-141.

$2850 \pm 160$

$\delta^{13} C=-24.3 \%$

Charcoal from dark humic soil matrix 14 to $17 \mathrm{~cm}$ below surface. Comment: sample too small for base rinse. Comment (KRF): sample dates non-microblade cultural occupation, HiTpl.

SFU-142.

$1430 \pm 160$ $\delta^{13} \mathrm{C}=-25 \%$

Wood from $25 \mathrm{~cm}$ below surface, subm to date assoc obsidian flake artifacts. Comment (KRF): min limiting date on microblade component, HiTpl.

SFU-143.

$260 \pm 80$ $\delta^{13} C=-26.4 \%$

Charcoal from bulk sample $7 \mathrm{~cm}$ below surface. Comment (KRF): min limiting date for non-microblade component, HiTpl; actual age better represented by SFU-141.

SFU-144.

Modern

Charcoal from hearth feature, 5 to $10 \mathrm{~cm}$ below surface. Comment $(\mathrm{KRF})$ : feature is prehistoric, date must reflect recent contamination.

SFU-145.

$600 \pm 80$

Charcoal from 4 to $6 \mathrm{~cm}$ below surface, subm to date assoc calcined bone and obsidian flakes. Comment (KRF): dates isolated hearth and flaking sta, HiTpl.

SFU-146.

$\mathbf{8 4 7 0} \pm 120$ $\delta^{13} C=-27.1 \%$

Peat from $115 \mathrm{~cm}$ below surface, subm to date basal sediments. Comment (KRF): min age for stabilization of modern drainage and slopes, and beginning of organic sedimentation at modern tree line.

SFU-147.

$3910 \pm 120$

Charcoal. Comment (KRF): dates upper, non-microblade cultural level at HiTp63.

SFU-262.

$1140 \pm 80$

$\delta^{13} C=-25 \%$

Charcoal from $8 \mathrm{~cm}$ below surface, subm to date assoc concentration of flakes. Comment (KRF): min limiting date on microblade component.

SFU-263.

$4990 \pm 130$

Peat from $37 \mathrm{~cm}$ below surface, subm to date lowest ash layer. Com ment (KRF): directly overlies same ash overlain by SFU-129. I suggest that this date should be adjusted $1 \sigma$ to $4860 \mathrm{BP}$. 
SFU-264.

$4630 \pm 100$

Peat from $35 \mathrm{~cm}$ below surface. Comment (KRF): directly antedates massive fall of coarse tephra and postdates earlier fine ash fall.

SFU-265.

Modern

Peat overlying highest ash layer just below bog surface. Comment (KRF): top 10 to $20 \mathrm{~cm}$ of bog affected by solifluction.

SFU-266.

$4560 \pm 170$

$\delta^{13} \mathrm{C}=-25 \%$

Peat underlying lowest ash layer, $40 \mathrm{~cm}$ below surface. Comment (KRF): date is too recent, considering SFU-129 and -263 overlying same ash. I suggest $2 \sigma$ adjustment to $4900 \mathrm{BP}$.

SFU-267.

Modern

Peat overlying cinder layer $20 \mathrm{~cm}$ below surface. Comment (KRF): too recent; sample probably affected by recent organic contamination or solifluction mixing.

Northwest Territories

\section{Karluk Island series}

Collagen from bones excavated at two sites on coast of Karluk $\left(75^{\circ}\right.$ $\left.30^{\prime} \mathrm{N}, 97^{\circ} 16^{\prime} \mathrm{W}\right)$. Samples subm to determine Paleo-Eskimo occupation of Arctic Archipelago. Samples coll and subm by J W Helmer, Arctic Inst North America, Calgary, Alberta.

\section{SFU-85.}

$1440 \pm 120$

Collagen from mixed land mammal bone (Arctic fox, musk-ox, polar bear) excavated from midden site, $\mathrm{QjLd}-17$, at $\mathrm{S}$ end of island, +4 to $6 \mathrm{~m}$.

\section{SFU-82.}

$$
\mathbf{2 5 3 0} \pm \mathbf{1 2 0}
$$

Collagen from Arctic fox bone. Sample coll from millen site, QjL 21 , on $\mathrm{W}$ coast of island, +10 to $11 \mathrm{~m}$.

\section{Bathurst Island series}

Collagen from mammal bone excavated from two sites near tip of Markham Point, Bathurst. Samples coll and subm by J W Helmer.

\section{SFU-87.}

$$
1520 \pm 200
$$

Collagen from musk-ox bone and antler excavated at longhouse site, QiLf-25, $+7 \mathrm{~m}$.

SFU-81.

$$
\begin{array}{r}
\mathbf{2 3 3 0} \pm \mathbf{1 2 0} \\
\delta^{13} C=-19.5 \%
\end{array}
$$

Collagen from musk-ox bone excavated from tent-ring site, QiLf-4, +11 to $12 \mathrm{~m}$. 
Alberta

SFU-119.

$$
2820 \pm 80
$$

Collagen from bison bone excavated at Strathcona Science Park site FiPi-29, Edmonton $\left(53^{\circ} 33^{\prime} \mathrm{N}, 113^{\circ} 22^{\prime} \mathrm{W}\right)$. Bone is from bison-processing area of Middle Prehistoric lithic workshop and habitation site. Sample subm to date earliest occupation of site; coll and subm by Jon Driver, Dept Archaeol, Simon Fraser Univ. Comment (JD): date probably too late for earliest (Oxbow) component due to mixing and compressed stratigraphy.

Ontario

\section{Fox Lake Project series}

Charcoal from CdHk-3 site, Ontario (46 $\left.36^{\prime} 45^{\prime \prime} \mathrm{N}, 81^{\circ} 43^{\prime} 45^{\prime \prime} \mathrm{W}\right)$. Samples coll and subm by Christopher Hanks, Dept Sociol and Anthropol, Univ British Columbia. See also Hanks (ms) for additional information.

SFU-151. $690 \pm 180$

Charcoal from feature believed to be hearth from Woodland period.

SFU-152.

$170 \pm 120$

Charcoal to date base of culture-bearing podzol layer.

SFU-153.

$$
\mathbf{3 7 0} \pm 90
$$

Charcoal from feature believed to be hearth of Woodland origin.

SFU-154.

$610 \pm 80$

Charcoal from feature believed to be hearth, assoc with single body sherd of ceramic vessel.

SFU-155.

$1450 \pm 250$

Charcoal from feature believed to be hearth with Late Woodland assoc.

SFU-169.

Charcoal from feature related to Woodland period occupation.

$$
480 \pm 260
$$

SFU-170.

$1320 \pm 700$

Charcoal from feature consisting of reduction flakes made of graywacke. Comment: sample too small for base rinse.

SFU-171.

$1840 \pm 350$

Charcoal subm to date base of culture-bearing podzol layer.

\section{Peace River Series I}

Charcoal and bone from HbRf-62 site $\left(56^{\circ} 11^{\prime} 47^{\prime \prime} \mathrm{N}, 120^{\circ} 55^{\prime} 35^{\prime \prime}\right.$ W), from low terrace at confluence of Peace and Moberly Rivers, $+426 \mathrm{~m}$. Samples coll and subm by Diana Alexander for Peace River Archaeol Proj, Dept Archaeol, Simon Fraser Univ. 
SFU-165.

Charcoal from 20 to $25 \mathrm{~cm}$ below surface, subm to date assoc lithic and bone material.

SFU-166.

$\mathbf{3 6 5 0} \pm \mathbf{3 0 0}$

$\delta^{13} C=-20.4 \%$ o

Collagen from antler 25 to $30 \mathrm{~cm}$ below surface. Sample subm to date assoc lithic concentration.

\section{Vallican Series I}

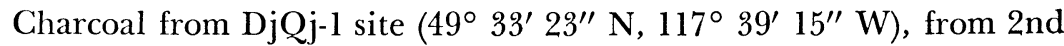
and 3rd major terrace above Slocan R, $0.7 \mathrm{~km} \mathrm{NW}$ of confluence of Little Slocan and Slocan Rivers. Village and burial site with $2000 \mathrm{yr}$ min occupation. Samples date several cultural depressions; coll and subm by Gordon Mohs.

SFU-175.

$260 \pm 100$

Charcoal from base of matrix containing Late Prehistoric material 15 to $20 \mathrm{~cm}$ below surface. Sample subm to date max age of Late Prehistoric deposits and assoc quartz crystal microblade core.

SFU-176.

Modern

Charcoal from hearth 27 to $29 \mathrm{~cm}$ below surface in circular cultural depression. Sample subm to date depression and assoc artifacts.

SFU-177.

$1250 \pm 120$

Charcoal from burial cavity 20 to $30 \mathrm{~cm}$ below surface. Sample subm to date burial.

SFU-178.

$260 \pm 200$

Charcoal from hearth 55 to $60 \mathrm{~cm}$ below surface. Sample subm to determine amount of embankment slumpage and river erosion at site.

SFU-179.

$480 \pm 200$

Charcoal from concentration of faunal remains 3 to $6 \mathrm{~cm}$ below surface. Sample subm to date latest occupation of cultural depression during Late Prehistoric period.

SFU-180.

$1040 \pm 110$

Charcoal from black soil matrix within circular house-pit depression. Sample subm to date occurrence of circular house-pit type.

SFU-181.

$1780 \pm 80$

Charcoal from hearth 45 to $65 \mathrm{~cm}$ below surface. Sample subm to date earliest occupation of cultural depression.

SFU-182.

$1170 \pm 260$

Charcoal from hearth 58 to $80 \mathrm{~cm}$ below surface. Sample subm to establish intermediate date of occupation of cultural depression. 
SFU-183.

$860 \pm 400$

Charcoal from soil matrix 85 to $87 \mathrm{~cm}$ below surface in cultural depression. Sample subm to date occupation of depression.

SFU-184.

$790 \pm 150$

Charcoal from hearth 25 to $29 \mathrm{~cm}$ below surface in rectangular depression. Sample subm to date period of Kutenai occupation of site.

SFU-185.

$220 \pm 100$

Charcoal from soil matrix 13 to $25 \mathrm{~cm}$ below surface in cultural depression. Sample subm to date latest occupation.

SFU-186.

$980 \pm 250$

Charcoal from hearth 13 to $20 \mathrm{~cm}$ below surface in cultural depression. Sample subm to determine min age that small circular depressions were used in Slocan area.

SFU-187.

Modern

Charcoal from hearth 5 to $20 \mathrm{~cm}$ below surface in cultural depression. Sample subm to date upper component of depression.

SFU-188.

$700 \pm 110$

Charcoal from soil matrix 23 to $30 \mathrm{~cm}$ below surface in circular housepit depression. Sample subm to date upper component of house-pit and assoc midden deposits.

SFU-189.

$1020 \pm 150$

Charcoal from soil matrix 52 to $54 \mathrm{~cm}$ below surface in house-pit depression. Sample subm to date lower component of house-pit and assoc tools.

SFU-190.

$1860 \pm 150$

Charcoal from hearth 90 to $100 \mathrm{~cm}$ below surface in house-pit depression. Hearth feature probably antedates construction of house-pit; sample thus establishes max date of use of house-pit.

SFU-191.

$750 \pm 90$

Charcoal from hearth 47 to $52 \mathrm{~cm}$ below surface located centrally within platform excavated into terrace embankment. Sample subm to date occupation of feature.

SFU-192.

$110 \pm 80$

Charcoal from hearth 25 to $35 \mathrm{~cm}$ below surface in platform excavated into terrace. Sample subm to date utilization of feature.

SFU-193.

$700 \pm 100$

Charcoal from lowermost component of house-pit depression. Sample subm to date earliest occupation of house pit. 
SFU-194.

$760 \pm 140$

Charcoal from base of platform 40 to $43 \mathrm{~cm}$ below surface. Sample subm to date utilization of feature.

\section{SFU-198.}

$2210 \pm 180$

Charcoal from hearth 44 to $50 \mathrm{~cm}$ below surface in circular house-pit depression. Sample subm to date use of house pit.

\section{Tanzania Series I}

\section{B. Tanzania}

Charcoal from DkBll sites. Samples coll and subm by F T Masao, Nat Mus Tanzania, Dar Es Salaam.

\section{SFU-137.}

$2020 \pm 360$

Charcoal from $1.1 \mathrm{~m}$ below surface from gravel layer in silty matrix. Sample subm to date assoc lithic artifacts.

\section{SFU-138.}

$2290 \pm 100$

Charcoal from $0.8 \mathrm{~m}$ below surface in layer of compacted silty clay. Sample subm to date assoc microlithic artifacts.

SFU-139.

Charcoal from $0.8 \mathrm{~m}$ below surface in layer of compacted silty clay. Sample subm to date assoc microlithic artifacts.

\section{SFU-140.}

Charcoal from 70 to $80 \mathrm{~cm}$ below surface in layer of silty gravel. Sample subm to date assoc microlithic and megalithic artifacts.

$$
\text { C. Fiji }
$$

\section{SFU-118. Rotuma}

$1000 \pm 100$

Collagen from human bone excavated from site Rot 2-9, Risumu, Dist Oinafa $\left(12^{\circ} 27^{\prime} 28^{\prime \prime} \mathrm{S}, 177^{\circ} 21^{\prime} 34^{\prime \prime} \mathrm{E}\right)$. Sample from 90 to $100 \mathrm{~cm}$ below surface dates site on Rotuma where first Tongan immigrants landed. Sample coll and subm by Richard Shutler, Jr, Dept Archaeol, Simon Fraser Univ. Comment (RS): according to Rotuman mythology, Risumu is site where first Tongans landed. Therefore, it is probable that this sample dates Tongan arrival.

\section{REFERENCES}

Hanks, Chris, (ms), 1981, Archaeology of the Spanish River: On file with Ontario Heritage Foundation.

Nelson, D E and Hobson, K A, 1982, Simon Fraser University radiocarbon dates I: Radiocarbon, v 24, p 344-351. 